RESEARCH PAPER

\title{
Political Economy of Smuggling: The Living Source for the Natives (A Case Study of Jiwani-Iran Border, Baluchistan)
}

\author{
${ }^{1}$ Abdul Raheem* ${ }^{2}$ Dr. Ikram Badshah ${ }^{3}$ Wasia Arshed
}

1. M.Phil. Scholar, Department of Anthropology, Quaid-e-Azam University, Islamabad, Pakistan

2. Assistant Professor, Department of Anthropology, Quaid-e-Azam University, Islamabad, Pakistan

3. M.Phil. Scholar, Department of Anthropology, Quaid-e-Azam University, Islamabad, Pakistan

\begin{tabular}{|c|c|}
\hline PAPER INFO & ABSTRACT \\
\hline $\begin{array}{l}\text { Received: } \\
\text { October 16, } 2021 \\
\text { Accepted: } \\
\text { December 29, } 2021 \\
\text { Online: } \\
\text { December } 31,2021\end{array}$ & $\begin{array}{l}\text { This study explores the political economy of smuggling on Jiwani-Iran } \\
\text { border. The natives are majorly involved in illegal transportation of } \\
\text { goods and objects, therefore; the study sets to explain how significant } \\
\text { smuggling for the local people is. It describes the kinship role in } \\
\text { reciprocity of their trade and transportation. The qualitative methods }\end{array}$ \\
\hline $\begin{array}{l}\text { Keywords: } \\
\text { Drugs, } \\
\text { Human, } \\
\text { Navigation, } \\
\text { Political Economy, } \\
\text { Reciprocity, } \\
\text { Smuggling, } \\
\text { Trafficking }\end{array}$ & $\begin{array}{l}\text { such as purposive sampling and interview guide were employed for } \\
\text { data collection. The research findings revealed that local people were } \\
\text { satisfied with their illegal trading which is depended largely on their } \\
\text { expertise and know-how of smuggling at borders. They disclosed that } \\
\text { their total economy was predominantly based on smuggling of stuff } \\
\text { like drugs, diesel, oil, gas, petrol, ration food from Iran, and human }\end{array}$ \\
\hline $\begin{array}{l}\text { *Corresponding } \\
\text { Author: } \\
\text { rahimsyed } 011 @ g m \\
\text { ail.com }\end{array}$ & $\begin{array}{l}\text { trafficking. They also enjoyed the privilege of possessing Sajjil } \\
\text { (Iranian identity card), thus; the dual nationality helped them in their } \\
\text { daily business and rahdari (border crossing agreement), enabling } \\
\text { them to travel to Iran for multiple purposes. }\end{array}$ \\
\hline
\end{tabular}

Introduction

This paper aims to analyze the people's living standard with Iran border where people tend to depend on the border economy (Huskin, 1993). Etymologically noted, the word that contains its ancestry in the Low German Schmuggeln, means 'to lurk'. Thus, a smuggler is not only a person participating in the secret transport of goods and people, but someone who smuggles and is potentiality dangerous as well ethically contested. According to Pitt, it is a phenomenon often presents in state with illegal commodity business is a black market for foreign exchange. Smuggling has a long and dialectical history (Pitt, 1983). In Britain, smuggling started at the end of the eighteenth century and turned out to be economically significant. Later, many first-world countries had to work hard to accommodate a high number of immigrants smuggled across national borders and this became an extra-legal business. (M, 2006). The smugglers, to avoid the payment of taxes at the check posts and other customs charges, relied on speed and swiftness to cross the 
border, particularly in the Gulf of Mexico where they had named the smuggling vessels "Gofast boats" (Tachuk, 2007). In the period of 1990-2009, the smuggling records of 183 countries are estimated in terms of cause and effects, and it was discovered that smuggling had positive outcomes for labor force involvement ratio in developed states (Wajid, Aziz, \& Iqbal, 2014). In contrast, it had a negative effect for developing countries. The total 183 countries' data demonstrated that governmental tax collection decreased when smuggling increased (Wajid, Aziz, \& Iqbal, 2014). Nationally, Pakistan has been recognized for the human trafficking. According to this report, 22,424 Pakistanis were deported from Oman, Iran, and Turkey. In Pakistan, the operational definition of human trafficking is enlisted in section $2(\mathrm{~h})$ of the prevention of human trafficking ordinance. The definition of section 2 (h) criminalizes the human smuggling (UNODC, 2013). Illegal transfer of commodities of both agricultural and nonagricultural to or from Pakistan is carried out at Iran and Afghanistan borders. Spots and routes of Chaman, Pishin, Badeen, Punjgor regions are used to smuggle from Afghanistan to Balochistan and, Mand, Taftan, Nokandi, Gwadar and Jiwani spots are used for smuggling from Iran (Sharif, Farooq \& Bashir, 2000). Agricultural commodities such as dry fruits are smuggled from Afghanistan to Balochistan. In contrast, oil, gas, fish, rations, and construction materials are smuggled from Iran to Balochistan (Sharif, Farooq, \& Bashir, 2000). In Jiwani-Iran border, I have searched out the disparities of legal and illegal goods and services that are transported at the same time and the same destinations. However, much trading and transportation is based on illegal transactions through illegal process.

\section{Literature Review}

The term "Political Economy" used in the discussion of comparative system of economy is much popular especially in the discussion of relevant merits of "socialism and capitalism". The Marxist thinkers preserved this brand of political economy respectably. The arguments of as Marxists urged its role as method of economics in which political and social organization interact in conflicting zone (Basley, 2007). As Charles S. Maier proposed a political economy approach: "interogates economic doctrines to disclose their sociological and political premises, in sum it regards economic ideas and behaviour not as framework for analysis, but as beliefs and actions that must themselves be explained". This approach forms Andrew Gamble's approach "The Free Economy and the Strong State" (Mayer, 1987). It sees the political structure in the policy outcomes that how institutions generate policy outcomes. It provides a way of thinking on how to make government intervention more effective. The New Political Economy is re-engaging with the art of existing Political Economy as a mental picture by the classical Economists. Having said that, it has not taken into account the study of practical policy making as any less scientific than other branches of economics (Basley, 2007). In the measurement model, indicators for smuggling of illegal goods brought conceptual definition of illegal smuggling refers to the 
flow of illicit drugs and informal immigrants from Mexico to the United States (Eichler \& Buehn, 2009).

Illicit economies comprise of unauthorized economic transaction, services, and commodities. These economies are either completely banned by national or international governments, or they are partially permitted to require certain licenses, certification and come under the fold of taxation. The unlawful economies include the cultivation of illegal crops like opium etc., human trafficking, smuggling of wildlife and money laundering (Felbab-Brown, 2009). Most of the heroin that passes through East and southern Africa is destined for markets in Europe, which are far more profitable than the African markets. The transit heroin trade is a bulk trade: though shipments are sometimes broken down into smaller consignments to avoid detection, much heroin transported this way is moved in units of tens or even hundreds of kilograms at a time (Hysom, Gastrow, Shaw \& 2018). Linking the literature, that states the inability of the countries that do not give enough attention to illicit economies brewing in their own land realize but only later that the regulated economic activities had crossed the limit and went out of the legal domain (Felbab- Brown, 2009).

On the other hand, the Turkish cross-border smuggling of illicit oil trade networks function through kinship, ethnic tribe and religious connection. Similarly, the Kurds in Iran and Iraq and Azerbaijan carry on smuggling due to their religious ties with Republican of Nahkchivian who moblize their ethnic and religious connections with of Shi'a-Muslim who facilitate their trade networks (Bozcali, 2011). For 16 years, in the village of Wilde in the province of Buenos Aires, Elbio Oscar Fernandez operated a company dedicated to stealing vehicles, dismantling them, and selling their parts (Dewey, 2012). Moreover, the setup of 'shuttle trade' (The activity in which individual entrepreneurs buy goods from abroad and import them for resale in street markets or small shops) is genuinely based on the legal excuse of a federal resolution from August 1, 1996 that leaves free private persons to import merchandise up to 50 kilograms or US\$ 1000 in the crucial as "a personal weight allowance toll-free into the Russian Federation" (Holzlehner, 2014). In general, in the social exchange, trust is a focal component of social solidarity and the brick to maintain the correlation within the social networks that compile the structure of society. Trust is elaborated as the real psychosocial distance among individuals. The utilization of social networks depends on interpersonal trust (Adler, 2004).

On the Chilean middle class Lomnitz found (Lomnitz \& Melnick, 1991), the roots of trust in an ethnographic study; a culturally described system of exchange called "compadrazgo" (alluding to the closeness that God parenthood implies in Catholic Church), which was based on trust among individuals. The mentioned system included an ongoing exchange of harmonizing services performed and motivated within an ideology of friendship. Ledeneva describes blat as an informal exchange system based on interpersonal bonds of trust by which individuals solve their daily lives' problems (Ledeneva, 1998). In 
the Indian economy, smuggling has been accepted to exist as a giant form of economic activity. State has imposed all sorts of counter smuggling and put restrictions on imports by contacting government officials. Exchange trend maybe contracted by purchase and sale of commodities by traders in the black market. By exchanging either articles are sold in black market at higher prices than official prices of the foreign currency or imported out of the official sanctions (Sen, S., 1975). As Tengku Umar quoted that "The smuggling will never stop as long as seawater is still seawater and as long as the sea still has water in it, smuggling will continue in the Riau Islands". When the British and Dutch started to make spaces in economic interest in the straits of Malacca, smuggling has become an interacting part of life in Riau Islands (Lyons, L. \& Ford, M., 2012). Tanzi (1983) presented monetary approach for gauging the scope of concealed economy in the United States, wherein, it is claimed that illegal transactions are mainly supported out using cash, and thus, the changes in illegal transactions can be perceived by looking at the changes in currency demand in the economy (Mahammood \& Ahmad, 2015).

The complexity of conveying the full import of what is occurring is due to the fact that while Europe's immigration and asylum process is rapidly evolving into a border control regime that operates in the areas of doubtful legality, its immediate securitization perfectly lends this evolution a rational polish by redefining the forced migrants as illegal, branding unregulated attempts to enter Europe as criminal acts, endangering national and regional security (Cetti, 2014). One of the most apparent objections to the elimination of interior border controls within the Europe must surely be the encouragement which such a closure of customs checks would offer to the international drug trade, substantively easing the problems involved in moving illicit drugs supplies around, at least within the European market (Tylor, 1992).

\section{Theoretical Framework}

Bhagwati (1981), in his article proposed a concept termed, "Illegal Trade through legal Entry points" where illegal trade occurs through legal entry points, i.e., where it is proclaimed and passed through customs, the way it occurs must involve some form of fake invoicing. First, that faked invoicing may be undertaken without the bribe-induced cooperation of customs officers. The implications of the two methods of faking voices to secure illegal importation are different since the former is likely to involve a (direct) real cost to the country in so far as the faking will require the collaboration of exporter at risk and hence, compensation, whereas the latter requires a bribe which is, in economic terms, only a transfer payment between nationals of the importing country.

The above theoretical discussion presents a magnificent scope for applying the data collected in the field. The concept indicated regarding the illegal trading through legal entry points where exporter or trader smuggle goods and services by giving bribery. This concept 
implies on data significantly as the identical situation is prevailing in Jiwani-Iran border that is in tehsil Jiwani in Gwadar District, Balochistan province of Pakistan. The channel of smuggling researched in the Jiwani-Iran border includes the types of smuggling: ration, diesel, oil, gas, and human trafficking are being traded through bribery culture with the concern law enforcement departments. This concept adequately justified the collected data because Bhagwati investigates similar plans for the smuggling of illegal transportation between countries.

\section{Material and Methods}

This research is based on the qualitative research methods. The study investigated the political economy of smuggling as people's living style with border economy. The universe of the study was tehsil Jiwani, District Gwadar, Balochistan (province in Pakistan). The target population of the research was traders and workers, working with the border economy. The sample size of the research was 16 common border laborers and 14 businessmen, selected through employing purpose sampling technique The interview guide schedule was used to collect the relevant data for analysis. The thematic analysis technique was used for generating themes from data. The researcher expands the study on a wider level and research ethics were carefully observed during the study.

\section{Results and Discussion}

\section{Historical background of Smuggling (Shapoki) in Jiwani}

Shapoki (smuggling) is a Balochi word used as a substitute for smuggling. It has a definition of non-customized transportation of goods and services. Smuggling from the Iran border is an undocumented phenomenon as the no official ever reported this typical type of smuggling to the higher quarter. As the people of the locale are/were involved in Shapoki for the last many centuries as per the local encounters. As narrated by one of the elderly respondents, (mara dahn wati pith o perokaan hosh kanth ma eda shapoki kanaga ent)," they remember their fathers, and grandfathers, smuggling different kinds of goods and services from immemorial time". The Jiwani-Iran border also has a history of trafficking children to foreign countries (Persia, Turkey, the gulf, and many European countries) for selling out their bodily organs. In return, smugglers traded cosmetics, wine, and gold from abroad countries.

Still, due to the absence of government policies, people in Jiwani mainly rely on Iran's border smuggling. Instead of being illegal transportation, native perceived smuggling as a profitable activity, because Jiwani people do not have an alternate source of income and no other subsistence to satiate their basic needs. A small number of people are meeting their economic need from the fishery sector, while majority of population rely on smuggling for the fulfilment of basic needs and amenities. 
The economy of shapoki (smuggling) in Jiwani is based on the nature of crossborder transactions through the sea line of Jiwani and Iran. Everything is transported or social mobility occurs in the context of cross-border whether it is in the form of drugs, human trafficking, and ration goods, export imports, or in the form of natural resources such as diesel, oil, gas, and petrol. The pattern of reciprocity and business partnership is contingent on the kinship ties based on the comparative settlement of Iran and Jiwani, Balochistan. As local people have their relatives on both sides of the border so strong networks based kinships always provide a cover to smuggling. The authorities of both side failed to detect them. The reciprocal coordination based on kinship system is mainly responsible for the sustenance and uninterrupted supply of various goods from both sides.

\section{Types of Smuggling}

Felbab-Brown (2009) asserted that the illicit economies comprises of unauthorized economic transactions, services, and commodities. These economies are either completely banned by national or international governments, or they are partially permitted to require certain licenses, certification and come under the fold of taxation. The political economy of smuggling is based on an illegal transaction with a different way in different borders with different goods and services as mentioned below. Jiwani-Iran border is used by local people to transport and smuggled various edible things, petroleum products etc. which are either not available in the local area or available a reasonable rate on Iran side.

\section{Rations}

Rations (Food items) are brought from Iran by Kahiks (speed boats) from the route of Jiwani Hoor (the point where river water meets seawater). It is considered a conventional and legitimate shapoki (smuggling) in this region and is not considered a harmful activity in the eyes of custom and security officials. They intentionally overlook such type of smuggling of edible products. Since it bypasses custom checks and regulation, it is also defined as shapoki (smuggling) or illegal transportation academically (Eichler \& Buehn, 2009). Such type of smuggling is also generally experienced on Mexico-USA border. As per legal definition is concern it is illegal under the law but on humanitarian ground the smuggling of food items is considered legal ethically as narrated by one of the respondent.

As Jiwani and Gawader is as a fur flung area of Baluchistan and to supply and provide food items and petroleum products from Pakistan always added up the cost of that. This chain of supply is always maintains through smuggling from Iran. If the authority blocked the flow of such smuggled product it will create an acute food shortage and manifold increase in the prices. As one of the businessman narrated that, the prices often remained affordable and within the reach of local people. People of the area preferred 
Iranian goods and products due to good quality. Iranian products are not only good in quality but they are also more economical and affordable than the Pakistani products. As one of the respondent narrated that "Iranian products are less expensive, healthier and are meeting up all the standards for a good health. There is a negative perception prevailed about the Pakistani products, it is labeled as unhealthy and substandard. The most common products smuggled from Iran are, cakes, Wafer biscuit, tea milk, non processed fresh milk, Butter, Paneer, Dates, potato chips, cold drinks, juices, pees, bean, Tun mahi, tomato, banana and other fruits, watermelon, vegetables, flour, sugar, cooking oil, Egg, and seed etc.

Local people narrated that, (Pakistani chezan ma wa kar marz nakan ent, chia $k$ Pakistan e shay yak e wa giran anth o domi 2 number anth ahani thaha $h$ saaf o falgari nest) "People noted Pakistani products are more expensive and lacking in the quality as compared to Iranian products. They trust Iranian products as they never compromised on standard while Pakistani products are not only low in quality but circulate in market after the expiry date. For example, by comparing Pakistani drinking milk with Iranian's, the Pakistani milk products are more contaminated and they added more water to fresh milk as compared to Iranian fresh milk, that's why local people preferred Iran products over Pakistani products.

\section{Passengers}

The second type of shapoki (smuggling) is Musaffir kashi (transporting passengers) from Jiwani to Iran. It is also an old established business, which is/was practiced in Jiwani region for the last many centuries. Local people of Jiwani have their sajjils (identity card issued by Iranian government) to travel legally to Iran, and one who does not have sajjil(identity card) used Rahdari (border passing agreement) which is a legal agreement of staying in Iran for 15 days. But sometimes, they travel Iran without making Rahdari (border passing agreement) and most of passengers travel without making rahdari (border passing agreement). They are those passengers who travel Iran by speed boats for the purpose of shopping, visiting their relatives, or joining any marriage and death ceremonies. As health services are more affordable in Iran so people also travelled Iran for treatment of various ailment at a very affordable price. Such type of passengers usually does not have any sajjils.

In this regard the case study of an old man who works as transport agent for sending those passengers to Iran who do not have sajjil or any relatives in Iran. The old man (transport agent) narrated that, (9mana 40 sala burz ent $k$ man mardum baran Irana, e hama mardum ant $k$ be kas ant, man damaga mashoor an har bekasa $k$ kaar e kapi Irana ah mani kira ka anth. E marduma ma oda wati loga jagah daya man wati loga musafir khan e jod kurta oda ahan man warag, rehahish or transport e zar giran0) "he is doing this work for more than forty years. He quoted that such travelers do not have relative over there who approach him then he takes them to Iran illegally and provide them shelter there by 
charging them for rent, food, and accommodation, as he has constructed a guest house in his house for this purpose in Iran's region called bal ". Another respondent further added that (may kaar o baaar e daar o madaar bus mardumgiri ent) "the total business is carried out with Iran is based on kinship ties as people are living from both side of border belong to same Baloch ethnic identity".

\section{Human Trafficking}

The third type of shapoki (smuggling) is Mardum barri (human trafficking). Human trafficking is a very old kind of shapoki (smuggling) which Jiwani border is regularly witnessing. Felbab-Brown (2009) noted that the illegal economies include the cultivation of illegal crops like opium etc., human trafficking, smuggling of wildlife, and money laundering. A group of shapok (smugglers) smuggles Afghans (pattans) from Afghanistan to Iran and further to Turkey where they continue their further journey to European countries. As local travel agents narrated that, (may pith o peroki kaar hamesh ent chia $k$ pesha sarhad nabetha mulkani encho giro band ham nabothag ma rahan $\mathrm{hm}$ pohtah ent haas kar ma Iran e rawag e drowaheen duz rahan zan ent) "they are involved in human smuggling since their ancestors do because they are expert in navigating sea routes specially Iran's. As one of respondents shared that they only take responsibility of sending immigrants to Iran and further several other agents (travel agents) take them to Turkey where they continue their journey toward European countries". This journey of traveling from Jiwani is also dangerous as a research respondent shared his experience bellow.

A boat captain narrated an incident that took place in 2012. He was a boat captain who used to transport Afghans from Jiwani to Iran. He was aware of sea route that was considered safe but said that "it was night and weather was very rough and a strong wind was blowing. He was smuggling 23 Afghans in his Kahik (speed boat). Kahik was hit by a storm and destroyed. All Afghans died". And the Kahik (speed boat) captain was injured but became disabled. He reasons for the death of Afghans was that they couldn't swim, so there was no chance of their survival from the violent storm. He survived due to his swimming skills and expertise.

\section{Smuggling Diesel, Oil, and Gas}

Smuggling of diesel, oil, petrol, and gas is practiced long before in the Jiwani region from Iran. This type of smuggling has contributed handsomely to the Jiwani economy as well as to some other regions. Smugglers buy diesel, oil, gas, and petrol from the Chabahar region and bring them by Kahiks (speed boat) to Jiwani hoor. As observed, diesel is very useful for them as the low prices of oil products make it affordable to the local people. If government banned the Iranian oil, it would raise the price of diesel beyond the capacity of the common man. The prices of diesel, petrol, oil, and gas remain stable and 
affordable due to the regular and uninterrupted supply from Iran through smuggling. The present prices of petroleum and gas are mentioned in table.

Table 1

\begin{tabular}{cccc}
$\begin{array}{c}\text { Prices of Iranian Petroleum Products in Iran and Pakistan } \\
\text { Petroleum } \\
\text { Products }\end{array}$ & $\begin{array}{c}\text { Prices In } \\
\text { Iran }\end{array}$ & $\begin{array}{c}\text { Prices in Pakistan } \\
\text { after Informal Tax }\end{array}$ & $\begin{array}{c}\text { Price of Petroleum } \\
\text { Products of Pakistan's }\end{array}$ \\
\hline Diesel & 36 & 85 & 143 \\
\hline Petrol & 41 & 90 & 146 \\
\hline Mobile Oil & 95 & 200 & 300 onward \\
\hline Gas & 90 & 120 & 150 \\
\hline
\end{tabular}

The market holders shared that, (e k niharani tapawath astent e drost pakistan $e$ forces hani tax anth) the huge difference in Iranian Products is due to illegal taxes of different Pakistani forces such as, Navy, Coast Guard, MI, FIA, FC, Army, Levies, and local police.

Bozcali (2011) mentioned in his article that the Turkish cross-border smuggling of illicit oil trade networks functions through kinship, ethnic tribe, and religious connections. The kinship cooperation is as identical noted by Bozcali. People living in Jiwani and Iranian Balochistan (Sistan-Balochistan) are relatives. Their kin ties eased out their reciprocal and dealing patterns with each other.

\section{Drugs Trafficking}

The fifth type of shapoki (smuggling) is Manshyiat froshi (drug smuggling). Drug smuggling is also carried out from the Jiwani border. They export various types of drugs to many other countries such as Somalia, Tanzania, Saudi Arabia, and many other Gulf countries. It is one of the most dangerous kinds of smuggling perceived by natives that have been practiced in the Jiwani-Iran border. If the smugglers safely transport their drugs to other countries, they earn handsome profits, but if they are caught by international forces, they end up spending their entire lives in jails and suffer millions of economic losses.

Markovits (2009) said that the opium trade in Malawi mobilized various types 'of operators at native state where peasants cultivated poppy and prepared drugs. They then carried these to the coast where they shipped them to China. The 'illegal' Malawa opium shipped them through Sindh. Drug traffickers smuggle opium, heroin, marijuana, and many hazardous drugs from the Jiwani-Iran border to Somalia, Tanzania, Saudi Arabia, Dubai, and European countries as well. 


\section{Political Dimension of Smuggling}

The economy of smuggling in Jiwani is political due to the community's interests. They smuggle drugs, traffic human, diesel, oil, petrol and ration: all these are practiced on kinship consensus and the government does intervene into such types of smuggling directly rather the government official take handsome amount of money as a bribe which further help the smugglers to evade custom duty and levy. The political dimension of smuggling is based on the kinship ties from both places, Iran and Jiwani. In this border trade, people trust kinship because the boat captains, crews, navigators, and shelter providers in Iran and Jiwani belong to the same community (Baloch). In the smuggling of diesel, petrol, gas, and oil, the kin-based reciprocity again surfaces on the border from both sides and are close relatives who assist each other in their transportation to Pakistan. If they come directly to Pakistan, their speed boats and ship will be confiscated by Pakistani forces. That is why kinship is considered a very important part of this dimension of smuggling. Likewise, people who do the business of ration foods found that kinship plays its' imperative role in the accumulation of wealth by having sajjils and rahdari.

\section{Discussion}

Smuggling is one of the main economies on the Jiwani border which is subsisting in the locale from time immemorial with no written authentic historical evidence except local narrations that they are living here and practicing cross-border trading and trafficking since ages. There border economy is running through kinship reciprocity. As research topic described the political dimensions of shapoki (smuggling), the prime focus was how the institution of illegal economy is running there (Klooster, 1998). Historically, the political economy in the time of colonial historiography has been little studied. However, in recent years, several historians have started filling this vacant slot. The study highlighted the role reciprocity of the same ethnic group residing on Jiwani-Iran border. How the kinship system has provided a cover to smuggling from both sides by dogging to security forces excise and taxation officials. (Basley, 2007). It scrutinizes the political structure in the policy outcomes that how institutions generate policy outcomes. It provides a perspective on how to make government intervention more effective. With the case of the Jiwani-Iran border, the Pakistani government failed in making any effective policy due to its unstable economic position, which is why government is unable to pay-services to the natives (Adler, 2004). The reciprocity is further strengthen by the social solidarity among kinsmen from both sides. The mutual trusts among the people of various networks of smugglers further boost up this system of smuggling. This border business would not be possible without the strong networks of kinship and same ethnicity. A similar policy was maintained by the government where people preferred to engage in smuggling at borders than the government-based work (government jobs). However, research focused on the historical importance of the Jiwani-Iran border for the natives of Jiwani where people believe in the 
border. The border is the only source of income for many businessmen and laborers living near the border. On both sides of the borders people living having same ethnic ties, so they don't have any formal setup for reciprocity they trust on verbal communication. Moreover, the research analyzed the problems that how the institution of economic transactions is being performed informally and to what extent people of Jiwani are getting a helpful hand from border trading. On the other hand, the conceptual framework also identified that people attempt to legally transport their illegal goods and services through bribery and extortion.

\section{Conclusion}

The Jiwani-Iran border economy is based on the politics of kinship. The kinship is the mighty factor for maintaining the business ties among businessmen that helps them every time to solve their trading problems. That is the reason that they do not prefer the government to hold over this institution rather they believe to ensure and strengthen the maintenance of border economic structure. In case they face any conflict or any issue pertinent to smuggling, they do not acknowledge the government's intervention, but seek help from local jirgha system patronized by a well honorable figures of the area. The intrakinship-based economy has brought them on a single unit to reciprocate each other.

Smuggling is a far-reaching subject, and it has not been explored to date. It stretches into countries in the Far East as well as in the Gulf region and northern and central Africa. The human trafficking aspect which is the sign of cruelty and brutality is still in need of extensive anthropological investigative fieldwork and to find their social networks as well as to study further what kind of religious background they have and what kind of political ideologies they follow and practice. The focus of the study documented the overall patterns of smuggling where people are dependent on the border economy. Local inhabitants of the region not only meet their economic needs from the smuggled products, Shapoki is also main source to further strengthen their ties with their kins on other side of the border. In crux, the Jiwani-Iran border is of great importance not only in terms of transportation of goods and services, but it also helps people smooth flow of mobility from Pakistan to Iran and from Iran to Pakistan. This mobility enabled border-based-population in meeting the relatives in marriage, death, and other ceremonies. 


\section{References}

Adler, L. (2004). Trust, social Networks and the Informal Economy: A Comparative Analysis. Review of sociology, 10(1), 5-26.

Basley, T. (2007). The New Political Economy. The Economic Journal, 117(524), 570-587.

Bhagwati, J. (1981). Theories of illegal Trade: Economic Consequences and Statistical Detection. Springer, 117(H.3), 409-427.

Bozcali, F. (2011). The illegal oil trade along Turkey's borders. Middle East Report, 261, 2429.

DAWN. (22 November 2018). Rare fish Known for medical use auctioned at whopping Rs 1.14. DAWN.

Dewey, M. (2012). Illegal Police protection and Market for stolen Vehichles in Buenos Aires. Cambridge University Press, 44,(4), 679-702.

Eichler, S. \& Buehn, A. (2009). Smuggling Illegal versus Legal Goods across U.S.-Mexico Border: A Structural Equations Model Approach. Southern Economic Journal, 76(2), 328-350.

Everett, M. (1979). The Trade Unoin movement in Frica. The Journal of Modern African Studies, 183.

Felbab-Brown, V. (2009). The Political Economy of illegal Domains in India and China. The international Lawers, 43(4), 1411-1428.

Huskin, T. (1993). The Practice and culture of smuggling in borderland of Egypt and Lybia. Royal institute of international Affairs.

Holzlehner, T. (2014). Trading against the State: 11/ Legal Cross-border Networks in the Russian Far East. Stiching Etnofoor, 26,(1), 13-38.

Hysom, S. \& Gastrow, P. \& Shaw, M. (june 2018). The herion coast: A Political Economy along the Eastern African Seaboat. Europan Union.

Adler, L. (2004). Trust, social Networks and the Informal Economy: A Comparative Analysis. Review of sociology, 10(1), 5-26.

Basley, T. (2007). The Economic journal, The New Political Economy, 117(524.), Pp. 570-587. 
Basley, T. (2007). The New Political Economy. The Economic Journal, 117(524), 570-587.

Bozcali, F. (2011). The illegal oil trade along Turkey's borders. Middle East Report, 261, 2429.

Cetti, F. (2014). Border controls in Europe: Policies and Practices outside the law. Pluto journal, 3,(1), 4-28.

Dewey, M. (2012). Illegal Police protection and Market for stolen Vehichles in Buenos Aires. Cambridge University Press, 44,(4), 679-702.

Eichler, S. \& Buehn, A. (2009). Smuggling Illegal versus Legal Goods across U.S.-Mexico Border: A Structural Equations Model Approach. Southern Economic Journal, 76(2), 328-350.

Felbab- Brown, B. (2009). The Political Economy of Illegal Domains in India and China. The International Lawyer, 43(4), 1411-1428.

Holzlehner, T. (2014). Trading against the State: 11/ Legal Cross-border Networks in the Russian Far East. Stiching Etnofoor, 26,(1), 13-38.

Hysom, S., Gastrow, P. \& Shaw, M. (june 2018). The herion coast: A Political Economy along the Eastern African Seaboat. Europan Union.

In search off Stabilityy: Explorations in Historical Political Economy. (1987). In S. Mayer, The free economic and strong state, (pp. 3-6). Cambridge university Press.

Ledeneva, A. (1998). Russia's Economy of Favors: Blat, networking and informal Exchange. Cambridge University Press.

Lomnitz, L. \& Melnick, A. (1991). Chile's middle class. A struggle for survival in the face of neoliberalism. Lynne Rienner Publishers.

Lyons, L. \& Ford, M. (2012). Smuggling Cultures in the Indonesia-Singapore Borderlands. In B. K. Sur, Transnational flows and Permissive Polities. Amsterdam University Press.

Mayer. (1987). In search off Stabilityy: Explorations in Historical Political Economy In S., The free economic and strong state, (pp. 3-6). Enlamd: Cambridge university Press.

M, J. (2006). The causalstructureof land price determinants. Canadian journal of Agriculture Economics, 54(2), 227-45. 
Klooster, W. (1998). The Plitical Economy of Smuggling: Reginal informal economies in early Bourboon New Granda. The Hisporic American Hisrorical Review. 337-338.

Markovits. (2009). The Political Economy of Opium Smuggling in early nineteenth century India: Leakage or Resistance? Modern Asian studies,, 43(1), 89-111.

Mahammood, R. \& Ahmad, E. (2015). Measurement of Import Smuggling in Pakistan. Pakistan Journal of Applied Economics, 25(2), 135-159.

Pitt, M. M. (1983). Smuggling and the black Market:. international Economy, 16, 243-257.

Sharif, M. Farooq, U. \& Bashir, A. (2000). Illegal Trade of Pakistan with Afghanistan and Iran through Balochistan: Size, Balance and loss to the public Exchequer. international general of Agriculture and Biology., 199-203.

Sen, S. (1975). Smuggling, Exchange Controls and Indian Economy. Economic and Political Weekly, 10(5/7,), 205-216.

Tachuk, K. L. (2007). Transational threats: Smuggling and trafficking in arms, drugs, and human life. Praeger Security International General Interest., 1, 50-62.

UNODC. (July, 2014). Recent trends of human trafficking and migrant smuggling to and from Pakistan. Pakistan: UNODC Pakistan office.

Wajid, Z., Aziz, B. \& Iqbal, Z. (Jan-Dec 2014). Smuggling arround the World: An Emperical investigation of causes and Indicators. Forman Journal of Economic Studies., 10, 105133. 